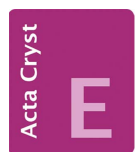

CRYSTALLOGRAPHIC COMMUNICATIONS

ISSN 2056-9890

Received 12 October 2021

Accepted 21 December 2021

Edited by V. Jancik, Universidad Nacional Autónoma de México, México

Keywords: 4-[(benzylamino)carbonyl]-1methylpyridinium; molecular structure; crystal structure; Hirshfeld surface analysis.

CCDC references: $2130345 ; 2130344$

Supporting information: this article has supporting information at journals.iucr.org/e

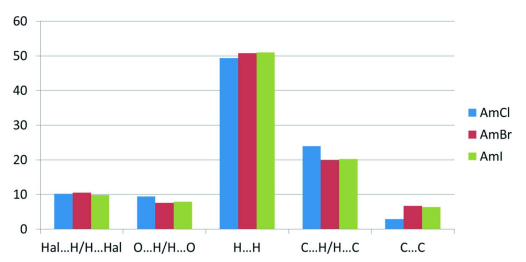

\section{4-[(Benzylamino)carbonyl]-1-methylpyridinium halogenide salts: $X$-ray diffraction study and Hirshfeld surface analysis}

\author{
Svitlana V. Shishkina, ${ }^{\mathrm{a}, \mathrm{b} *}$ Anna M. Shaposhnik, ${ }^{\mathrm{a}}$ Vyacheslav M. Baumer, ${ }^{\mathrm{a}}$ Vitalii V. \\ Rudiuk $^{\mathrm{c}}$ and Igor A. Levandovskiy ${ }^{\mathrm{d}}$
}

aSSI "Institute for Single Crystals", NAS of Ukraine, 60 Nauky ave., Kharkiv, 61001, Ukraine, 'b.N. Karazin Kharkiv
National University, 4 Svobody sq., Kharkiv, 61022, Ukraine, ' ${ }^{\mathbf{F}}$ Farmak JSC, 63 Kyrylivska str., Kyiv, 04080, Ukraine, and
${ }^{\mathbf{d}}$ Kyiv National Technical University of Ukraine, 37 Pobedy ave., Kyiv, 03056, Ukraine. *Correspondence e-mail:
sveta@xray.isc.kharkov.com

Two salts of 4-[(benzylamino)carbonyl]-1-methylpyridinium (Am) with chloride $\left(\mathrm{C}_{14} \mathrm{H}_{15} \mathrm{~N}_{2} \mathrm{O}^{+} \cdot \mathrm{Cl}^{-}\right)$and bromide $\left(\mathrm{C}_{14} \mathrm{H}_{15} \mathrm{~N}_{2} \mathrm{O}^{+} \cdot \mathrm{Br}^{-}\right)$anions were studied and compared with the iodide salt. AmCl crystallizes in the centrosymmetric space group $P 2_{1} / n$ while $\mathbf{A m B r}$ and $\mathbf{A m I}$ form crystals in the Sohncke space group $P 2_{1} 2_{1} 2_{1}$. Crystals of $\mathbf{A m B r}$ are isostructural to those of $\mathbf{A m I}$. The cation and anion are bound by an $\mathrm{N}-\mathrm{H} \cdots \mathrm{Hal}$ hydrogen bond. Hirshfeld surface analysis was used to compare different types of intermolecular interactions in the three structures under study.

\section{Chemical context}

Organic salts are of great importance for the pharmaceutical industry (Stahl \& Wermuth, 2002). Many drugs are produced in the form of salts because of their higher solubility as compared to neutral compounds. The pharmacokinetic properties may be modified by the choice of counter-ion (Guerrieri et al., 2010; He et al., 2018). Therefore, the study of the ability of an active pharmaceutical ingredient to form salts with different ions is an actual problem.

4-[(Benzylamino)carbonyl]-1-methylpyridinium iodide is known as a multimodal antiviral drug (Buhtiarova et al., 2003; Frolov et al., 2004; Boltz et al., 2018; Cocking et al., 2018). This salt crystallized in the $P 2_{1} 2_{1} 2_{1}$ orthorhombic space group and was studied by single-crystal X-ray diffraction, powder diffraction, IR spectroscopy and DSC (Drebushchak et al., 2017). Screening varying different solvents and crystallization conditions did not reveal the formation of any other polymorphs.<smiles>O=C(NCc1ccccc1)c1cc[n+]([N+](=O)[O-])cc1</smiles>

In the present work we studied salts of the 4-[(benzylamino)carbonyl]-1-methylpyridinium cation with chloride and bromide anions and compared their molecular and crystal structures with that of the iodide salt. 


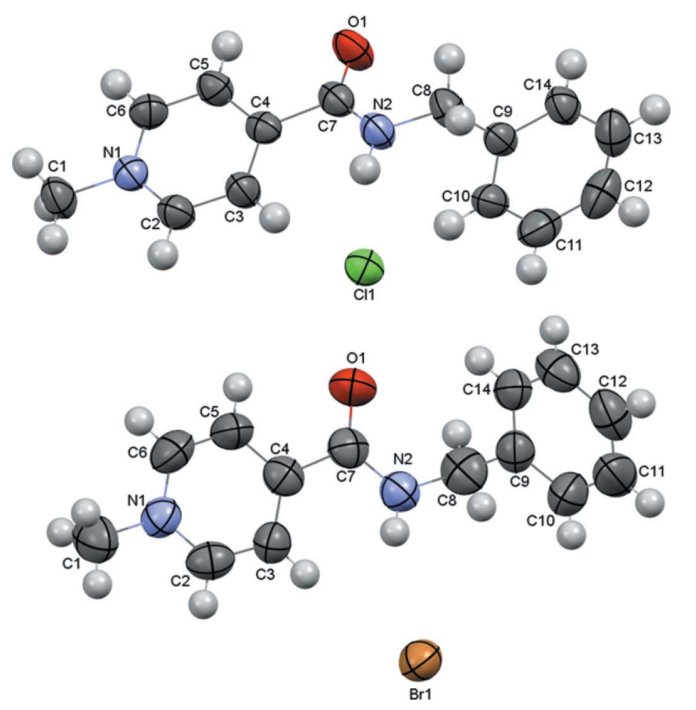

$\mathrm{AmCl}$

$\mathrm{AmBr}$

Figure 1

Molecular structures of the title 4-[(benzylamino)carbonyl]-1-methylpyridinium halogenide salts. Displacement ellipsoids are shown with $50 \%$ probability level.

\section{Structural commentary}

Usually organic salts are obtained following hydrogen transfer within an acid-base pair. The equilibrium between the neutral acid-base pair and their cation-anion pair depends on external conditions such as temperature, concentration, nature of solvent, etc (Stahl \& Nakano, 2002). As a result, organic cations formed upon protonation are not stable and can be deprotonated. The quaternization of the pyridine nitrogen atom also results in cation formation (Wei et al., 2018). However, such a cation is much more stable than its protonated analogue and can form salts with different anions.

The organic cation is formed due to the quaternization of the pyridine moiety in the two salts under study (Fig. 1). The positive charge is located at the pyridine nitrogen atom. The carbamide group and the pyridine ring are slightly noncoplanar in the chloride salt and coplanar in the bromide salt

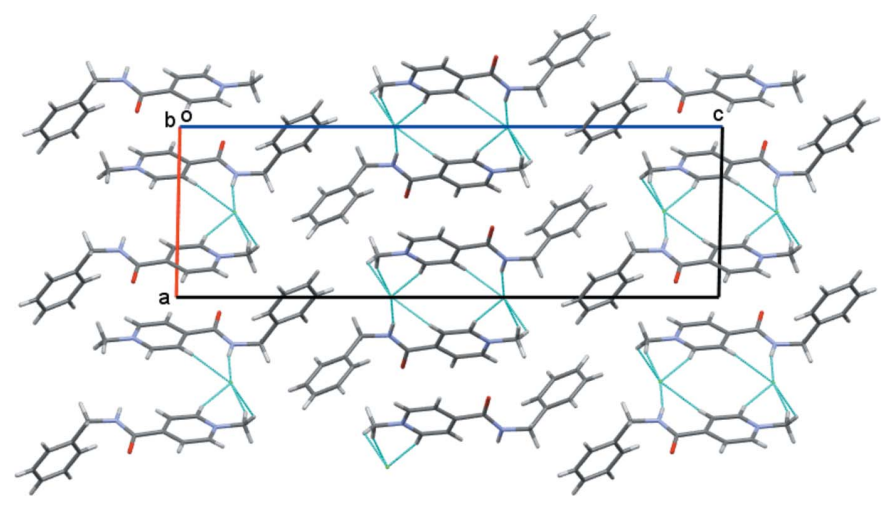

Figure 2

Crystal structure of 4-[(benzylamino)carbonyl]-1-methylpyridinium chloride. $X-\mathrm{H} \cdots \mathrm{Cl}$ hydrogen bonds are shown as dashed cyan lines. [the $\mathrm{C} 5-\mathrm{C} 4-\mathrm{C} 7-\mathrm{O} 1$ torsion angle is $-13.3(4)^{\circ}$ in $\mathbf{A m C l}$ and $-1.4(16)^{\circ}$ in $\left.\mathbf{A m B r}\right]$. The intramolecular contacts $\mathrm{H} 2 \cdots \mathrm{C} 3=2.57 \AA, \mathrm{H} 2 \cdots \mathrm{H} 3=2.05 \AA$ in $\mathbf{A m C l}$ and $\mathrm{H} 2 \cdots \mathrm{C} 3=$ $2.65 \AA, \mathrm{H} 2 \cdots \mathrm{H} 3=2.16 \AA$ in $\mathbf{A m B r}$ are shorter than the sums of the corresponding van der Waals radii $(\mathrm{H} \cdots \mathrm{C}=2.87 \AA$ and $\mathrm{H} \cdots \mathrm{H}=2.34 \AA$; Zefirov, 1997) and point to a steric repulsion between the carbamide and pyridine fragments in the cations of AmCl and AmBr. The phenyl fragment of the benzyl substituent is positioned orthogonally to the carbamide unit and rotated around the $\mathrm{N} 2-\mathrm{C} 8$ bond [the $\mathrm{C} 7-\mathrm{N} 2-\mathrm{C} 8-\mathrm{C} 9$ torsion angle is $-88.1(4)^{\circ}$ in $\mathbf{A m C l}$ and $93.5(12)^{\circ}$ in $\mathbf{A m B r}$ while the $\mathrm{N} 2-\mathrm{C} 8-\mathrm{C} 9-\mathrm{C} 10$ torsion angle is $-24.3(4)^{\circ}$ in $\mathbf{A m C l}$ and 103.8 (12) in $\mathbf{A m B r}]$.

The AmCl salt crystallizes in the centrosymmetric $P 2_{1} / n$ space group while the $\mathbf{A m B r}$ salt crystallizes in the Sohncke space group $P 2_{1} 2_{1} 2_{1}$, similar to the AmI salt (Drebushchak et $a l ., 2017)$. The cation does not contain an asymmetric atom.

\section{Supramolecular features}

Analysis of the intermolecular interactions revealed that an $\mathrm{N}-\mathrm{H} \cdots \mathrm{Hal}$ intermolecular hydrogen bond is present in both of the salts under study (Tables 1 and 2). This hydrogen bond

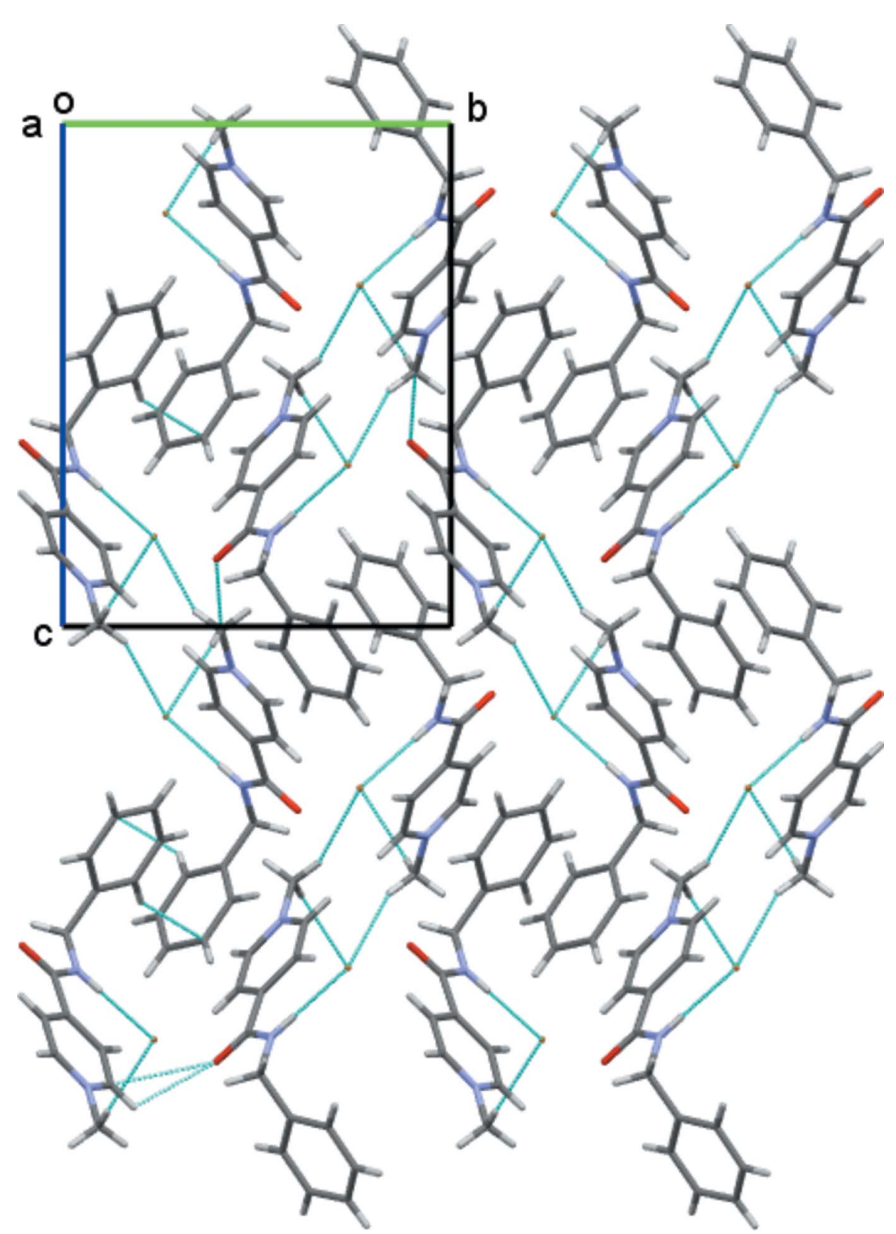

Figure 3

Crystal structure of 4-[(benzylamino)carbonyl]-1-methylpyridinium bromide. $X-\mathrm{H} \cdots \mathrm{Br}$ hydrogen bonds are shown as dashed cyan lines. 
Table 1

Hydrogen-bond geometry $\left(\AA{ }^{\circ}{ }^{\circ}\right)$ for AmCl.

\begin{tabular}{lllll}
\hline$D-\mathrm{H} \cdots A$ & $D-\mathrm{H}$ & $\mathrm{H} \cdots A$ & $D \cdots A$ & $D-\mathrm{H} \cdots A$ \\
\hline $\mathrm{N} 2-\mathrm{H} 2 \cdots \mathrm{Cl} 1$ & $0.92(3)$ & $2.26(3)$ & $3.163(3)$ & $165(2)$ \\
$\mathrm{C} 1-\mathrm{H} 1 C \cdots \mathrm{Cl} 1^{\mathrm{i}}$ & 0.96 & 2.89 & $3.513(3)$ & 124 \\
$\mathrm{C} 1-\mathrm{H} 1 A \cdots \mathrm{Cl} 1^{\mathrm{ii}}$ & 0.96 & 2.72 & $3.633(3)$ & 160 \\
$\mathrm{C} 2-\mathrm{H} 2 A \cdots \mathrm{Cl} 1^{\mathrm{ii}}$ & 0.93 & 2.59 & $3.474(3)$ & 160 \\
$\mathrm{C} 3-\mathrm{H} 3 \cdots \mathrm{Cl} 1$ & 0.93 & 2.63 & $3.531(3)$ & 165 \\
\hline
\end{tabular}

Symmetry codes: (i) $-x+2,-y+1,-z+1$; (ii) $-x+2,-y+2,-z+1$.

Table 2

Hydrogen-bond geometry $\left(\AA,^{\circ}\right)$ for $\mathbf{A m B r}$.

\begin{tabular}{lllll}
\hline$D-\mathrm{H} \cdots A$ & $D-\mathrm{H}$ & $\mathrm{H} \cdots A$ & $D \cdots A$ & $D-\mathrm{H} \cdots A$ \\
\hline $\mathrm{N} 2-\mathrm{H} 2 \cdots \mathrm{Br} 1$ & 0.86 & 2.68 & $3.468(9)$ & 154 \\
$\mathrm{C} 1-\mathrm{H} 1 A \cdots \mathrm{Br}^{\mathrm{i}}$ & 0.96 & 3.04 & $3.913(13)$ & 152 \\
$\mathrm{C} 1-\mathrm{H} 1 C \cdots \mathrm{Br}^{\mathrm{ii}}$ & 0.96 & 3.01 & $3.901(13)$ & 154 \\
\hline
\end{tabular}

Symmetry codes: (i) $x-\frac{1}{2},-y+\frac{1}{2},-z$; (ii) $x-1, y, z$.

(a)

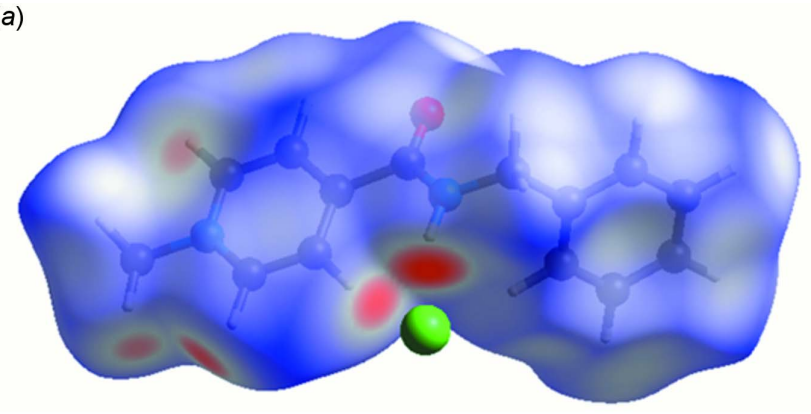

(b)

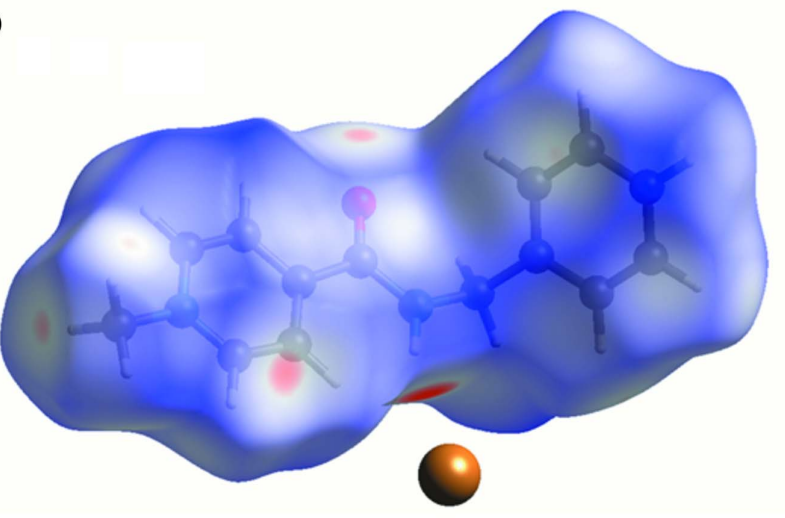

(c)

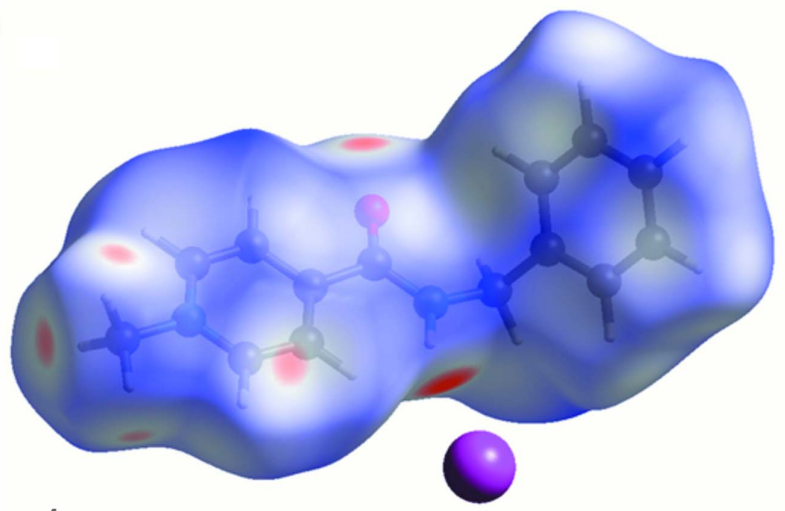

Figure 4

Hirshfeld surfaces of the cation in the (a) AmCl, (b) AmBr and (c) AmI salts mapped over $d_{\text {norm }}$.

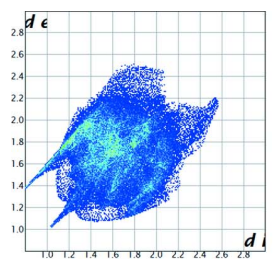

(a)

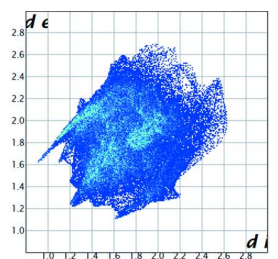

(b)

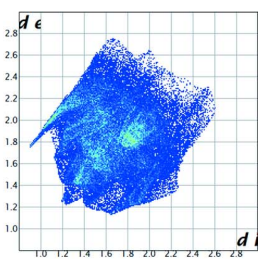

(c)
Figure 5

Two-dimensional fingerprint plots for the cation in the three salts under study: (a) AmCl, (b) AmBr and (c) AmI.

is strongest in the $\mathbf{A m C l}$ salt as a result of the higher negativity of chloride anions as compared to bromide and iodide counter-ions. In addition, a set of $\mathrm{C}-\mathrm{H} \cdots \mathrm{Cl}$ ' intermolecular hydrogen bonds is found in AmCl (Fig. 2) while only two C$\mathrm{H}$...Hal' hydrogen bonds are present in the crystal structure of $\mathbf{A m B r}$ (Figs. 3 and 4; Tables 1 and 2). Generally, the presence of pyridine and benzene rings in a molecule can lead to the formation of $\pi-\pi$ stacking interactions in the crystalline phase. However, no such stacking interactions were found in the $\mathbf{A m C l}$ and $\mathbf{A m B r}$ crystals.

\section{Hirshfeld surface analysis}

The formation of intermolecular interactions in the two salts under study and the AmI salt can be compared using Hirshfeld surface analysis and two-dimensional fingerprint plots [Turner et al., 2017]. The Hirshfeld surfaces were obtained for the cations using a standard high surface resolution, mapped over $d_{\text {norm}}$. The red spots on the $d_{\text {norm }}$ surfaces correspond to contacts that are shorter than the van der Waals radii sum of the closest atoms (Fig. 4). Such red spots are observed on all the hydrogen atoms participating in the above-mentioned intermolecular hydrogen bonds (Tables 1 and 2). It should be noted that the brightness of the spot on the hydrogen atom decreases with an increase in the radius of the halogen atom, indicating a weakening of the hydrogen bond.

The hydrogen bonds and short contacts of the cations found in the structures of $\mathbf{A m C l}, \mathbf{A m B r}$ and $\mathbf{A m I}$ are shown in the two-dimensional fingerprint plots presented in Fig. $5 a-c$. It should be noted that the fingerprint plots constructed for the

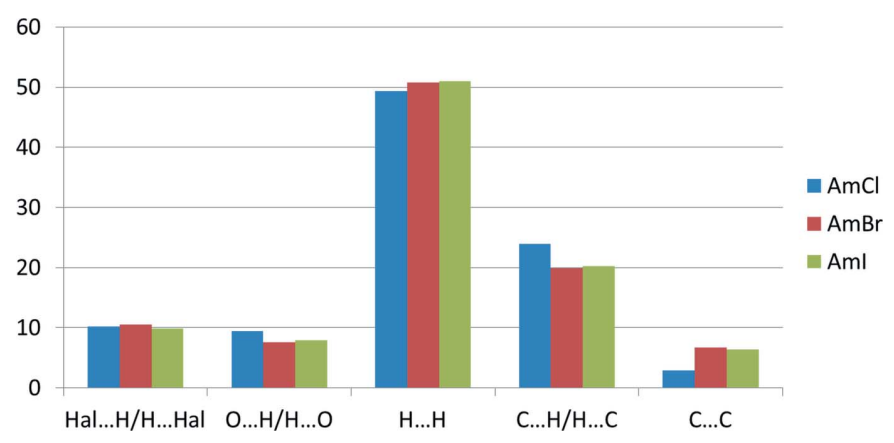

Figure 6

Contributions of the different types of interactions to the total Hirshfeld surface of the cation in three halogenide salts. 
Table 3

Characteristic vibration frequencies according to the FTIR data.

\begin{tabular}{llll}
\hline Location of bond & Vibrations & AmCl, wavenumbers & AmBr, wavenumbers \\
\hline Valence vibrations of monosubstituted amides & $\mathrm{N}-\mathrm{H}$ (stretching) & 3166 & 3198 \\
Valence vibrations (aromatic system) & $\mathrm{C}-\mathrm{H}$ (stretching) & 3049 & 3042 \\
Valence vibrations $\left(\mathrm{CH}_{3}\right.$ ) & $\mathrm{C}-\mathrm{H}$ (stretching) & 2994 & 3001 \\
Valence vibrations of the carboxyl group in amides & $\mathrm{C}=\mathrm{O}$ (stretching) & 1656,1572 & 1659,1571 \\
Vibrations of bonds in the pyridine ring & $\mathrm{C}-\mathrm{H}$ (out-of-plane bending) & 727,659 & 702,621 \\
\hline
\end{tabular}

cations in structures $\mathbf{A m B r}$ and AmI are very similar (Fig. $5 b$ and $5 c$ ). The main contribution to the total Hirshfeld surface (49.4\% in AmCl, 50.8\% in $\mathbf{A m B r}, 51.0 \%$ in $\mathbf{A m I}$ ) is provided by $\mathrm{H} \cdots \mathrm{H}$ short contacts (Fig. 6). The contribution of $\mathrm{C} \cdots \mathrm{H} /$ $\mathrm{H}$. . C contacts is much smaller but also significant $(23.9 \%$ in AmCl, $19.9 \%$ in $\mathbf{A m B r}, 20.2 \%$ in AmI). The similar contributions of $\mathrm{Hal} \cdots \mathrm{H} / \mathrm{H} \cdots \mathrm{Hal}$ contacts $(10.2 \%$ in AmCl, $10.5 \%$ in $\mathbf{A m B r}, 9.9 \%$ in $\mathbf{A m I})$ and $\mathrm{O} \cdots \mathrm{H} / \mathrm{H} \cdots \mathrm{O}$ contacts $(9.4 \%$ in AmCl, 7.6\% in $\mathbf{A m B r}, 7.9 \%$ in $\mathbf{A m I}$ ) are slightly surprising because of the absence of $X-\mathrm{H} \cdots \mathrm{O}$ intermolecular interactions in the structures under study. The presence of two aromatic rings in the cation could result in the formation of stacking interactions in the crystal, but the contribution of the C $\cdots$ C contacts is the smallest $2.9 \%$ in $\mathbf{A m C l}, 6.7 \%$ in $\mathbf{A m B r}$, $6.4 \%$ in $\mathbf{A m I}$ ). The small contribution of the C...C contacts agrees with the results of the traditional analysis of intermolecular interactions in a crystal using the shortest distances between atoms belonging to neighbouring molecules (see Supramolecular features section). It should be noted that the contribution of the C $\cdots \mathrm{C}$ contacts is more than twice as high in the crystals of AmBr and AmI compared to AmCl. This can be explained by a mutual orientation of the pyridine and benzene rings belonging to neighbouring molecules in the AmBr and AmI crystals. However, there are no effective $\pi-\pi$ interaction between these rings because the distances and angles between the planar $\pi$ systems are too large.

\section{Database survey}

A search of the Cambridge Structural Database (Version 5.42, update of November 2020; Groom et al., 2016) revealed the structure of the AmI salt (refcode BEBFIA; Drebushchak et al., 2017). A comparison with the AmBr and AmI crystal structures showed that they are isostructural.

\section{Synthesis and crystallization}

The synthesis of salts of 4-[(benzylamino)carbonyl]-1methylpyridinium halide was carried out according to the reaction scheme below.

\section{Synthesis and crystallization of $\mathrm{AmCl}$.}

$520 \mathrm{~mL}$ of acetonitrile was cooled to $273-277 \mathrm{~K}$ in a glass flask. Chloromethane $(87.8 \mathrm{~g}, 1.739 \mathrm{~mol})$ was dissolved at this temperature. Benzylamide isonicotinic acid (245.78 g, $1.16 \mathrm{~mol}$ ) and $600 \mathrm{~mL}$ of cooled acetonitrile and acetonitrile solution saturated with chloromethane were loaded into an autoclave. The autoclave was closed and heated to $373 \mathrm{~K}$. The mixture was incubated for $3 \mathrm{~h}$ at this temperature. After that, the mixture was allowed to cool to room temperature. The reaction mixture was transferred into a glass flask and cooled to $273-275 \mathrm{~K}$. The reaction mixture was filtered and the precipitate was rinsed on the filter with $200 \mathrm{~mL}$ of cooled acetonitrile. The product was dried at $313 \mathrm{~K}$ for $12 \mathrm{~h}$. Yield $226 \mathrm{~g}$ of crude 4-[(benzylamino)carbonyl]-1-methylpyridinium chloride $(75 \%)$; white crystals.<smiles>OC(NCc1ccccc1)c1ccncc1</smiles><smiles>C[N+]1(C)C=CC(C(=O)NCc2ccccc2)=CC1</smiles>

$226 \mathrm{~g}$ of crude 4-[(benzylamino)carbonyl]-1-methylpyridinium chloride were dissolved in $265 \mathrm{~mL}$ of $90 \%$ ethanol and $660 \mathrm{~mL}$ of 2-propanol, and $4.25 \mathrm{~g}$ activated charcoal were added. The reaction mixture was heated to boiling point, stirred at boiling for $30 \mathrm{~min}$ and filtered. The obtained solution was let to spontaneously cool to a temperature of $303 \mathrm{~K}$, then to a temperature of $278-283 \mathrm{~K}$ in a cooling water bath, and stirred for $2 \mathrm{~h}$ at this temperature. The reaction mixture was filtrated and the precipitate rinsed on the filter with $110 \mathrm{~mL}$ of cold 2-propanol. The product was dried at $313 \mathrm{~K}$ for $12 \mathrm{~h}$. Yield $180.8 \mathrm{~g}$ of 4-[(benzylamino)carbonyl]-1-methylpyridinium chloride (80\%); white crystals; m.p. 474-477 K.

\section{Synthesis and crystallization of AmBr.}

4-[(Benzylamino)carbonyl]-1-methylpyridinium iodide $(57.7 \mathrm{~g}, 0.163 \mathrm{~mol})$, silver bromide $(33.77 \mathrm{~g}, 0.180 \mathrm{~mol})$ and $700 \mathrm{~mL}$ of water were loaded into a glass flask. The mixture was stirred for $72 \mathrm{~h}$. The sediment was filtered off. The solvent was evaporated under reduced pressure. $300 \mathrm{~mL}$ of acetonitrile were added to the precipitate and the mixture was refluxed for $2 \mathrm{~h}$. The reaction mixture was allowed to spontaneously cool to a temperature of $303 \mathrm{~K}$. The reaction mixture was filtered and the precipitate was rinsed on the filter with $50 \mathrm{~mL}$ of cold acetonitrile. The product was dried at $313 \mathrm{~K}$ for $12 \mathrm{~h}$. Yield $14 \mathrm{~g}$ of 4-[(benzylamino)carbonyl]-1methylpyridinium bromide (28\%); white crystals; m.p. 465$468 \mathrm{~K}$.

The crystals of $\mathbf{A m C l}$ and $\mathbf{A m B r}$ were grown as very small colourless and yellow parallelepipeds, respectively, in contrast to the well-grown yellow block-shaped crystals of AmI. 
Table 4

Experimental details.

\begin{tabular}{|c|c|c|}
\hline & AmCl & $\mathrm{AmBr}$ \\
\hline \multicolumn{3}{|l|}{ Crystal data } \\
\hline Chemical formula & $\mathrm{C}_{14} \mathrm{H}_{15} \mathrm{~N}_{2} \mathrm{O}^{+} \cdot \mathrm{Cl}^{-}$ & $\mathrm{C}_{14} \mathrm{H}_{15} \mathrm{~N}_{2} \mathrm{O}^{+} \cdot \mathrm{Br}^{-}$ \\
\hline$M_{\mathrm{r}}$ & 262.73 & 307.19 \\
\hline Temperature $(\mathrm{K})$ & 293 & 293 \\
\hline$a, b, c(\AA)$ & $8.5222(7), 5.6875(3), 27.1720(14)$ & $9.417(3), 11.099(5), 14.363(6)$ \\
\hline$\alpha, \beta, \gamma\left({ }^{\circ}\right)$ & $90,91.243(6), 90$ & $90,90,90$ \\
\hline$V\left(\AA^{3}\right)$ & $1316.71(15)$ & $1501.2(10)$ \\
\hline$\mu\left(\mathrm{mm}^{-1}\right)$ & 0.28 & 2.73 \\
\hline Crystal size $(\mathrm{mm})$ & $0.30 \times 0.20 \times 0.10$ & $0.30 \times 0.30 \times 0.06$ \\
\hline \multicolumn{3}{|l|}{ Data collection } \\
\hline Diffractometer & Xcalibur, Sapphire3 & Xcalibur, Sapphire3 \\
\hline Absorption correction & Multi-scan (CrysAlis PRO, Rigaku OD 2018) & Multi-scan (CrysAlis PRO, Rigaku OD 2018) \\
\hline$T_{\min }, T_{\max }$ & $0.624,1.000$ & $0.068,1.000$ \\
\hline \multicolumn{3}{|l|}{ Refinement } \\
\hline$R\left[F^{2}>2 \sigma\left(F^{2}\right)\right], w R\left(F^{2}\right), S$ & $0.051,0.119,1.05$ & $0.063,0.150,1.00$ \\
\hline No. of reflections & 2302 & 2635 \\
\hline No. of parameters & 168 & 164 \\
\hline H-atom treatment & $\begin{array}{l}\mathrm{H} \text { atoms treated by a mixture of independent } \\
\text { and constrained refinement }\end{array}$ & $\mathrm{H}$-atom parameters constrained \\
\hline$\Delta \rho_{\max }, \Delta \rho_{\min }\left(\mathrm{e} \AA^{-3}\right)$ & $0.18,-0.16$ & $0.34,-0.60$ \\
\hline Absolute structure & - & $\begin{array}{l}\text { Flack } x \text { determined using } 407 \text { quotients } \\
\qquad\left[\left(I^{+}\right)-\left(I^{-}\right)\right] /\left[\left(I^{+}\right)+\left(I^{-}\right)\right] \text {(Parsons et al., 2013) }\end{array}$ \\
\hline Absolute structure parameter & _- & $0.00(2)$ \\
\hline
\end{tabular}

Computer programs: CrysAlis PRO (Rigaku OD, 2018), SHELXT2014/5 (Sheldrick, 2015a), SHELXL2016/6 (Sheldrick, 2015b), Mercury (Macrae et al., 2020) and OLEX2 (Dolomanov et al., 2009).

\section{Spectroscopic characterization}

Both salts under consideration were fully characterized by IR, ${ }^{1} \mathrm{H}$ NMR and ${ }^{13} \mathrm{C}$ NMR spectroscopy. IR spectra of solid samples were acquired on a Thermo Fisher Scientific Nicolet iS50 FTIR spectrometer. ${ }^{1} \mathrm{H}$ NMR spectra of samples were measured in DMSO- $d_{6}$ on a $600 \mathrm{MHz}$ Varian spectrometer. ${ }^{13} \mathrm{C}$ NMR spectra of samples were taken in DMSO- $d_{6}$ on a $150 \mathrm{MHz}$ Varian spectrometer.

The characteristic vibration frequencies of the main functional groups according to the data of FTIR spectroscopy are shown in Table 3. The full spectroscopic data are presented below and in Figs. 7 and 8. As can be seen from Table 3, the

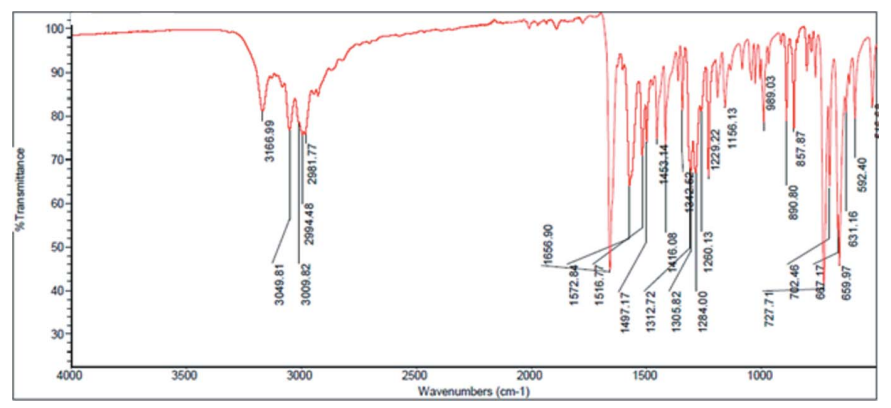

Figure 7

IR spectrum of the AmCl salt. main difference in IR spectra concerns the valence vibrations of the $\mathrm{N}-\mathrm{H}$ group and vibrations of $\mathrm{C}-\mathrm{H}$ bonds in the pyridine ring.

AmCl:

IR spectrum (cm ${ }^{-1}$ ) (Fig. 7): 592.40, 631.16, 659.97, 667.17, 702.46, 727.71, 857.87, 890.80, 989.03, 1156.13, 1229.22, $1260.13,1284.00,1305.82,1312.72,1342.62,1416.08,1453.14$, $1497.17,1516.77,1572.84,1656.90,2981.77,2994.48,3009.82$, 3049.81, 3166.99 .

${ }^{1} \mathrm{H}$ NMR (600 MHz, DMSO- $d_{6}$, p.p.m.): $\delta=4.40(s, 3 \mathrm{H}$, $\left.\mathrm{CH}_{3}\right), 4.48-4.49$ ( $\left.d, 2 \mathrm{H}, \mathrm{CH} 2\right), 7.21-7.36$ ( $\left.m, 5 \mathrm{H}, \mathrm{Ar}\right), 8.59$ ( $d$, 2H, Py), 9.21 (d, 2H, Py), 10.47 ( $s, \mathrm{H}, \mathrm{NH})$.

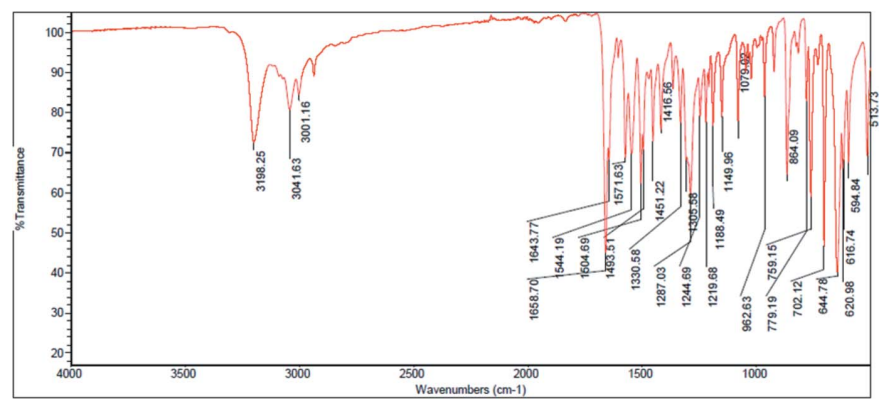

Figure 8

IR spectrum of the AmBr salt. 
${ }^{13} \mathrm{C}$ NMR (150 MHz, DMSO- $d_{6}$, p.p.m.): $\delta=43.42\left(\mathrm{CH}_{2}\right)$, 48.37 (CH3), 125.98, 146.94, 147.91 (Py), 127.44, 128.00, 128.75, 139.03 (Ar), $162.12(\mathrm{C}=\mathrm{O})$.

\section{AmBr:}

IR spectrum $\left(\mathrm{cm}^{-1}\right)$ (Fig. 8): 594.84, 616.74, 620.98, 644.78, $702.12,759.15,779.19,864.09$, 962.63, 1079.02, 1149.96, $1188.49,1219.68,1244.69,1287.03,1305.58,1330.58,1416.56$, $1451.22,1493.51,1504.69,1544.19,1571.63,1643.77,1658.70$, 3001.16, 3041.63, 3198.25.

${ }^{1} \mathrm{H}$ NMR (400 MHz, DMSO- $d_{6}$, p.p.m.): $\delta=4.41(s, 3 \mathrm{H}$, $\mathrm{CH} 3), 4.51(d, 2 \mathrm{H}, \mathrm{CH} 2), 7.23-7.36(m, 5 \mathrm{H}, \mathrm{Ar}), 8.48(d, 2 \mathrm{H}$, $\mathrm{Py}), 9.21$ (d, 2H, Py), 9.92 ( $s, \mathrm{H}, \mathrm{NH})$.

${ }^{13} \mathrm{C}$ NMR (100 MHz, DMSO- $d_{6}$, p.p.m.): $\delta=43.52(\mathrm{CH} 2)$, $48.50\left(\mathrm{CH}_{3}\right), 125.87,146.99,147.97$ (Py), 127.56, 128.00, 128.84, 138.83 (Ar), $162.31(\mathrm{C}=\mathrm{O})$.

\section{Refinement}

Crystal data, data collection and structure refinement details are summarized in Table 4. All of the hydrogen atoms were located in difference-Fourier maps. They were included in calculated positions and treated as riding with $\mathrm{C}-\mathrm{H}=0.96 \AA$, $U_{\text {iso }}(\mathrm{H})=1.5 U_{\text {eq }}$ for methyl groups and with $\mathrm{C}_{\mathrm{ar}}-\mathrm{H}=0.93 \AA$, $\mathrm{Csp} p^{2}-\mathrm{H}=0.97 \AA, U_{\text {iso }}(\mathrm{H})=1.2 U_{\text {eq }}$ for all other hydrogen atoms.

\section{Acknowledgements}

The authors are grateful to Farmak JSC for support of this work.

\section{Funding information}

Funding for this research was provided by: National Academy of Sciences of Ukraine (grant No. 0120U102660).

\section{References}

Boltz, D., Peng, X., Muzzio, M., Dash, P., Thomas, P. G. \& Margitich, V. (2018). Antivir. Chem. Chemother. pp. 26 https://doi.org/10.1177/ 2040206618811416

Buhtiarova, T. A., Danilenko, V. P., Homenko, V. S., Shatyrkina, T. V. \& Yadlovsky, O. E. (2003). Ukrainian Med. J. 33, 72-74.

Cocking, D., Cinatl, J., Boltz, D. A., Peng, X., Johnson, W., Muzzio, M., Syarkevych, O., Kostyuk, G., Goy, A., Mueller, L. \& Margitich, V. (2018). Acta Virol. 62, 191-195.

Dolomanov, O. V., Bourhis, L. J., Gildea, R. J., Howard, J. A. K. \& Puschmann, H. (2009). J. Appl. Cryst. 42, 339-341.

Drebushchak, T. N., Kryukov, Y. A., Rogova, A. I. \& Boldyreva, E. V. (2017). Acta Cryst. E73, 967-970.

Frolov, A. F., Frolov, V. M., Buhtiarova, T. A. \& Danilenko, V. P. (2004). Ukrainian Med. J. 39, 69-74.

Groom, C. R., Bruno, I. J., Lightfoot, M. P. \& Ward, S. C. (2016). Acta Cryst. B72, 171-179.

Guerrieri, P., Jarring, K. \& Taylor, L. S. (2010). J. Pharm. Sci. 99, 3719-3730.

He, Y., Orton, E. \& Yang, D. (2018). J. Pharm. Sci. 107, 419-425.

Macrae, C. F., Sovago, I., Cottrell, S. J., Galek, P. T. A., McCabe, P., Pidcock, E., Platings, M., Shields, G. P., Stevens, J. S., Towler, M. \& Wood, P. A. (2020). J. Appl. Cryst. 53, 226-235.

Parsons, S., Flack, H. D. \& Wagner, T. (2013). Acta Cryst. B69, 249 259.

Rigaku OD (2018). CrysAlis PRO. Rigaku Oxford Diffraction, Yarnton, England.

Sheldrick, G. M. (2015a). Acta Cryst. A71, 3-8.

Sheldrick, G. M. (2015b). Acta Cryst. A71, 3-8.

Stahl, P. H. \& Nakano, M. (2002). In Handbook of Pharmaceutical Salts: Properties, Selection, and Use edited by P. H. Stahl \& C. G. Wermuth, pp. 83-116. Weinheim: Wiley-VCH.

Stahl, P. H. \& Wermuth, C. G. (2002). Handbook of Pharmaceutical Salts: Properties, Selection, and Use. Weinheim: Wiley-VCH.

Turner, M. J., McKinnon, J. J., Wolff, S. K., Grimwood, D. J., Spackman, P. R., Jayatilaka, D. \& Spackman, M. A. (2017). CrystalExplorer17. University of Western Australia. http://Hirshfeldsurface.net

Wei, L., Chen, Y., Tan, W., Li, Q., Gu, G., Dong, F. \& Guo, Z. (2018). Molecules, 23, 2604-2616.

Zefirov, Yu. V. (1997). Kristallografiya, 42, 936-958. 


\section{supporting information}

Acta Cryst. (2022). E78, 114-119 [https://doi.org/10.1107/S2056989021013505]

\section{4-[(Benzylamino)carbonyl]-1-methylpyridinium halogenide salts: X-ray diffraction study and Hirshfeld surface analysis}

Svitlana V. Shishkina, Anna M. Shaposhnik, Vyacheslav M. Baumer, Vitalii V. Rudiuk and Igor

\section{A. Levandovskiy}

Computing details

For both structures, data collection: CrysAlis PRO (Rigaku OD, 2018); cell refinement: CrysAlis PRO (Rigaku OD, 2018); data reduction: CrysAlis PRO (Rigaku OD, 2018); program(s) used to solve structure: SHELXT2014/5 (Sheldrick, 2015a); program(s) used to refine structure: SHELXL2016/6 (Sheldrick, 2015b); molecular graphics: Mercury (Macrae et al., 2020); software used to prepare material for publication: OLEX2 (Dolomanov et al., 2009).

4-[(Benzylamino)carbonyl]-1-methylpyridinium chloride (AmCl)

\section{Crystal data}

$\mathrm{C}_{14} \mathrm{H}_{15} \mathrm{~N}_{2} \mathrm{O}^{+} \cdot \mathrm{Cl}^{-}$

$M_{r}=262.73$

Monoclinic, $P 2_{1} / n$

$a=8.5222(7) \AA$

$b=5.6875(3) \AA$

$c=27.1720(14) \AA$

$\beta=91.243(6)^{\circ}$

$V=1316.71(15) \AA^{3}$

$Z=4$

\section{Data collection}

Xcalibur, Sapphire3 diffractometer

Radiation source: Enhance (Mo) X-ray Source

Detector resolution: 16.1827 pixels $\mathrm{mm}^{-1}$

$\omega$ scans

Absorption correction: multi-scan

(CrysAlisPro, Rigaku OD 2018)

$T_{\min }=0.624, T_{\max }=1.000$

Refinement

Refinement on $F^{2}$

Least-squares matrix: full

$R\left[F^{2}>2 \sigma\left(F^{2}\right)\right]=0.051$

$w R\left(F^{2}\right)=0.119$

$S=1.05$

2302 reflections

168 parameters

0 restraints
$F(000)=552$

$D_{\mathrm{x}}=1.325 \mathrm{Mg} \mathrm{m}^{-3}$

Mo $K \alpha$ radiation, $\lambda=0.71073 \AA$

Cell parameters from 766 reflections

$\theta=3.2-20.4^{\circ}$

$\mu=0.28 \mathrm{~mm}^{-1}$

$T=293 \mathrm{~K}$

Block, colorless

$0.30 \times 0.20 \times 0.10 \mathrm{~mm}$

5343 measured reflections

2302 independent reflections

1529 reflections with $I>2 \sigma(I)$

$R_{\text {int }}=0.048$

$\theta_{\text {max }}=25.0^{\circ}, \theta_{\min }=3.0^{\circ}$

$h=-10 \rightarrow 9$

$k=-6 \rightarrow 6$

$l=-31 \rightarrow 26$

Hydrogen site location: mixed

$\mathrm{H}$ atoms treated by a mixture of independent and constrained refinement

$w=1 /\left[\sigma^{2}\left(F_{\mathrm{o}}{ }^{2}\right)+(0.034 P)^{2}\right]$

where $P=\left(F_{\mathrm{o}}^{2}+2 F_{\mathrm{c}}^{2}\right) / 3$

$(\Delta / \sigma)_{\max }<0.001$

$\Delta \rho_{\max }=0.18$ e $\AA^{-3}$

$\Delta \rho_{\min }=-0.16$ e $\AA^{-3}$ 


\section{Special details}

Geometry. All esds (except the esd in the dihedral angle between two 1.s. planes) are estimated using the full covariance matrix. The cell esds are taken into account individually in the estimation of esds in distances, angles and torsion angles; correlations between esds in cell parameters are only used when they are defined by crystal symmetry. An approximate (isotropic) treatment of cell esds is used for estimating esds involving l.s. planes.

Fractional atomic coordinates and isotropic or equivalent isotropic displacement parameters $\left(\AA^{2}\right)$

\begin{tabular}{|c|c|c|c|c|}
\hline & $x$ & $y$ & $z$ & $U_{\text {iso }} * / U_{\text {eq }}$ \\
\hline $\mathrm{Cl1}$ & $1.00363(10)$ & $0.87872(14)$ & $0.60412(3)$ & $0.0644(3)$ \\
\hline $\mathrm{O} 1$ & $0.5912(3)$ & $0.1775(4)$ & $0.57992(7)$ & $0.0685(7)$ \\
\hline N1 & $0.7393(3)$ & $0.5404(4)$ & $0.42221(8)$ & $0.0507(6)$ \\
\hline N2 & $0.7762(3)$ & $0.4394(5)$ & $0.60568(9)$ & $0.0568(7)$ \\
\hline $\mathrm{H} 2$ & $0.844(4)$ & $0.561(5)$ & $0.5990(10)$ & $0.063(10)^{*}$ \\
\hline $\mathrm{C} 1$ & $0.7545(4)$ & $0.6081(6)$ & $0.37003(9)$ & $0.0661(10)$ \\
\hline H1A & 0.822085 & 0.742522 & 0.367808 & $0.099 *$ \\
\hline H1B & 0.652886 & 0.646109 & 0.356333 & $0.099^{*}$ \\
\hline $\mathrm{H} 1 \mathrm{C}$ & 0.798499 & 0.479503 & 0.352058 & $0.099^{*}$ \\
\hline $\mathrm{C} 2$ & $0.8023(4)$ & $0.6758(5)$ & $0.45742(10)$ & $0.0586(9)$ \\
\hline $\mathrm{H} 2 \mathrm{~A}$ & 0.855209 & 0.812634 & 0.449031 & $0.070^{*}$ \\
\hline $\mathrm{C} 3$ & $0.7896(4)$ & $0.6142(5)$ & $0.50613(10)$ & $0.0594(9)$ \\
\hline H3 & 0.833718 & 0.709994 & 0.530460 & $0.071^{*}$ \\
\hline $\mathrm{C} 4$ & $0.7124(3)$ & $0.4127(5)$ & $0.51914(10)$ & $0.0469(7)$ \\
\hline $\mathrm{C} 5$ & $0.6493(4)$ & $0.2765(5)$ & $0.48176(10)$ & $0.0551(8)$ \\
\hline H5 & 0.595346 & 0.139381 & 0.489249 & $0.066^{*}$ \\
\hline C6 & $0.6655(4)$ & $0.3418(5)$ & $0.43357(11)$ & $0.0575(9)$ \\
\hline H6 & 0.624699 & 0.246639 & 0.408589 & $0.069^{*}$ \\
\hline $\mathrm{C} 7$ & $0.6881(4)$ & $0.3322(5)$ & $0.57169(11)$ & $0.0535(8)$ \\
\hline $\mathrm{C} 8$ & $0.7728(4)$ & $0.3762(5)$ & $0.65733(9)$ & $0.0603(9)$ \\
\hline H8A & 0.875072 & 0.408118 & 0.672190 & $0.072 *$ \\
\hline H8B & 0.754012 & 0.208480 & 0.659881 & $0.072^{*}$ \\
\hline $\mathrm{C} 9$ & $0.6503(4)$ & $0.5038(5)$ & $0.68622(9)$ & $0.0492(8)$ \\
\hline $\mathrm{C} 10$ & 0.5909 (4) & $0.7194(5)$ & $0.67180(11)$ & $0.0589(9)$ \\
\hline H10 & 0.626455 & 0.789378 & 0.643179 & $0.071^{*}$ \\
\hline C11 & $0.4807(5)$ & $0.8315(6)$ & $0.69903(12)$ & $0.0763(11)$ \\
\hline H11 & 0.441586 & 0.976239 & 0.688610 & $0.092 *$ \\
\hline $\mathrm{C} 12$ & $0.4267(5)$ & $0.7325(7)$ & $0.74176(13)$ & $0.0789(11)$ \\
\hline H12 & 0.349989 & 0.808053 & 0.759759 & $0.095^{*}$ \\
\hline $\mathrm{C} 13$ & $0.4875(4)$ & $0.5203(7)$ & $0.75753(11)$ & $0.0732(11)$ \\
\hline H13 & 0.454056 & 0.453721 & 0.786750 & $0.088^{*}$ \\
\hline C14 & $0.5986(4)$ & $0.4067(6)$ & $0.72969(10)$ & $0.0587(9)$ \\
\hline H14 & 0.638986 & 0.263078 & 0.740336 & $0.070^{*}$ \\
\hline
\end{tabular}

Atomic displacement parameters $\left(\AA^{2}\right)$

\begin{tabular}{lllllll}
\hline & $U^{11}$ & $U^{22}$ & $U^{33}$ & $U^{12}$ & $U^{13}$ & $U^{23}$ \\
\hline C11 & $0.0722(6)$ & $0.0577(5)$ & $0.0636(5)$ & $-0.0109(5)$ & $0.0095(4)$ & $-0.0002(4)$ \\
O1 & $0.0690(16)$ & $0.0706(15)$ & $0.0660(14)$ & $-0.0208(14)$ & $0.0031(12)$ & $0.0193(11)$
\end{tabular}


supporting information

\begin{tabular}{lllllll}
$\mathrm{N} 1$ & $0.0510(16)$ & $0.0512(15)$ & $0.0500(14)$ & $0.0014(14)$ & $0.0027(12)$ & $0.0026(12)$ \\
$\mathrm{N} 2$ & $0.0646(19)$ & $0.0573(17)$ & $0.0487(15)$ & $-0.0113(16)$ & $0.0033(14)$ & $0.0087(13)$ \\
$\mathrm{C} 1$ & $0.078(3)$ & $0.075(2)$ & $0.0447(16)$ & $-0.012(2)$ & $-0.0035(16)$ & $0.0126(15)$ \\
$\mathrm{C} 2$ & $0.070(2)$ & $0.0507(19)$ & $0.0552(19)$ & $-0.0110(18)$ & $-0.0021(17)$ & $0.0057(15)$ \\
$\mathrm{C} 3$ & $0.075(2)$ & $0.0558(19)$ & $0.0472(17)$ & $-0.0142(19)$ & $-0.0018(16)$ & $0.0038(14)$ \\
$\mathrm{C} 4$ & $0.0444(18)$ & $0.0435(17)$ & $0.0531(16)$ & $0.0006(15)$ & $0.0054(14)$ & $0.0046(14)$ \\
$\mathrm{C} 5$ & $0.055(2)$ & $0.0516(18)$ & $0.0588(18)$ & $-0.0087(17)$ & $0.0112(16)$ & $0.0044(15)$ \\
C6 & $0.062(2)$ & $0.0515(19)$ & $0.0585(19)$ & $-0.0118(18)$ & $0.0027(16)$ & $-0.0034(15)$ \\
C7 & $0.055(2)$ & $0.0516(19)$ & $0.0544(18)$ & $0.0023(18)$ & $0.0086(17)$ & $0.0095(15)$ \\
C8 & $0.064(2)$ & $0.068(2)$ & $0.0480(17)$ & $-0.0007(19)$ & $-0.0025(16)$ & $0.0127(15)$ \\
C9 & $0.056(2)$ & $0.0489(18)$ & $0.0422(15)$ & $-0.0129(16)$ & $-0.0083(14)$ & $0.0022(13)$ \\
C10 & $0.078(3)$ & $0.0464(18)$ & $0.0523(17)$ & $-0.0067(19)$ & $-0.0081(17)$ & $0.0038(15)$ \\
C11 & $0.098(3)$ & $0.057(2)$ & $0.073(2)$ & $0.012(2)$ & $-0.020(2)$ & $-0.0109(18)$ \\
C12 & $0.078(3)$ & $0.095(3)$ & $0.064(2)$ & $0.012(2)$ & $-0.003(2)$ & $-0.027(2)$ \\
C13 & $0.077(3)$ & $0.094(3)$ & $0.0485(18)$ & $-0.012(2)$ & $0.0034(19)$ & $-0.0030(19)$ \\
C14 & $0.069(2)$ & $0.062(2)$ & $0.0453(16)$ & $-0.0060(19)$ & $-0.0047(16)$ & $0.0079(15)$ \\
& & & & & & \\
\hline
\end{tabular}

Geometric parameters $\left(\stackrel{A}{A}{ }^{\circ}\right)$

\begin{tabular}{llll}
\hline $\mathrm{O} 1-\mathrm{C} 7$ & $1.230(3)$ & $\mathrm{C} 5-\mathrm{H} 5$ & 0.9300 \\
$\mathrm{~N} 1-\mathrm{C} 6$ & $1.332(3)$ & $\mathrm{C} 6-\mathrm{H} 6$ & 0.9300 \\
$\mathrm{~N} 1-\mathrm{C} 2$ & $1.332(4)$ & $\mathrm{C} 8-\mathrm{C} 9$ & $1.506(4)$ \\
$\mathrm{N} 1-\mathrm{C} 1$ & $1.478(3)$ & $\mathrm{C} 8-\mathrm{H} 8 \mathrm{~A}$ & 0.9700 \\
$\mathrm{~N} 2-\mathrm{C} 7$ & $1.326(4)$ & $\mathrm{C} 8-\mathrm{H} 8 \mathrm{~B}$ & 0.9700 \\
$\mathrm{~N} 2-\mathrm{C} 8$ & $1.450(3)$ & $\mathrm{C} 9-\mathrm{C} 10$ & $1.380(4)$ \\
$\mathrm{N} 2-\mathrm{H} 2$ & $0.92(3)$ & $\mathrm{C} 9-\mathrm{C} 14$ & $1.385(4)$ \\
$\mathrm{C} 1-\mathrm{H} 1 \mathrm{~A}$ & 0.9600 & $\mathrm{C} 10-\mathrm{C} 11$ & $1.366(4)$ \\
$\mathrm{C} 1-\mathrm{H} 1 \mathrm{~B}$ & 0.9600 & $\mathrm{C} 10-\mathrm{H} 10$ & 0.9300 \\
$\mathrm{C} 1-\mathrm{H} 1 \mathrm{C}$ & 0.9600 & $\mathrm{C} 11-\mathrm{C} 12$ & $1.379(5)$ \\
$\mathrm{C} 2-\mathrm{C} 3$ & $1.376(4)$ & $\mathrm{C} 11-\mathrm{H} 11$ & 0.9300 \\
$\mathrm{C} 2-\mathrm{H} 2 \mathrm{~A}$ & 0.9300 & $\mathrm{C} 12-\mathrm{C} 13$ & $1.378(5)$ \\
$\mathrm{C} 3-\mathrm{C} 4$ & $1.372(4)$ & $\mathrm{C} 13-\mathrm{C} 14$ & 0.9300 \\
$\mathrm{C} 3-\mathrm{H} 3$ & 0.9300 & $\mathrm{C} 13-\mathrm{H} 13$ & $1.385(4)$ \\
$\mathrm{C} 4-\mathrm{C} 5$ & $1.377(4)$ & $\mathrm{C} 14-\mathrm{H} 14$ & 0.9300 \\
$\mathrm{C} 4-\mathrm{C} 7$ & $1.518(4)$ & $\mathrm{O} 1-\mathrm{C} 7-\mathrm{N} 2$ & 0.9300 \\
$\mathrm{C} 5-\mathrm{C} 6$ & $1.371(4)$ & $\mathrm{O} 1-\mathrm{C} 7-\mathrm{C} 4$ & \\
& & $\mathrm{~N} 2-\mathrm{C} 7-\mathrm{C} 4$ & $125.0(3)$ \\
$\mathrm{C} 6-\mathrm{N} 1-\mathrm{C} 2$ & $120.6(2)$ & $\mathrm{N} 2-\mathrm{C} 8-\mathrm{C} 9$ & $119.5(3)$ \\
$\mathrm{C} 6-\mathrm{N} 1-\mathrm{C} 1$ & $119.7(3)$ & $\mathrm{N} 2-\mathrm{C} 8-\mathrm{H} 8 \mathrm{~A}$ & $115.5(3)$ \\
$\mathrm{C} 2-\mathrm{N} 1-\mathrm{C} 1$ & $119.7(3)$ & $\mathrm{C} 9-\mathrm{C} 8-\mathrm{H} 8 \mathrm{~A}$ & $114.5(2)$ \\
$\mathrm{C} 7-\mathrm{N} 2-\mathrm{C} 8$ & $122.5(3)$ & $\mathrm{N} 2-\mathrm{C} 8-\mathrm{H} 8 \mathrm{~B}$ & 108.6 \\
$\mathrm{C} 7-\mathrm{N} 2-\mathrm{H} 2$ & $123.7(17)$ & $\mathrm{H} 8 \mathrm{~A}-\mathrm{C} 8-\mathrm{H} 8 \mathrm{~B}$ & 108.6 \\
$\mathrm{C} 8-\mathrm{N} 2-\mathrm{H} 2-\mathrm{C} 9-\mathrm{C} 14$ & 108.6 \\
$\mathrm{~N} 1-\mathrm{C} 1-\mathrm{H} 1 \mathrm{~A}$ & $113.8(17)$ & 109.5 & 108.6 \\
$\mathrm{~N} 1-\mathrm{C} 1-\mathrm{H} 1 \mathrm{~B}$ & 109.5 & 109.5 & $118.4(3)$ \\
$\mathrm{H} 1 \mathrm{~A}-\mathrm{C} 1-\mathrm{H} 1 \mathrm{~B}$ & 109.5 & $\mathrm{C} 122.3(3)$ \\
$\mathrm{N} 1-\mathrm{C} 1-\mathrm{H} 1 \mathrm{C}$ & $\mathrm{H} 1 \mathrm{~A}-\mathrm{C} 1-\mathrm{H} 1 \mathrm{C}$ & &
\end{tabular}




\begin{tabular}{|c|c|c|c|}
\hline $\mathrm{H} 1 \mathrm{~B}-\mathrm{C} 1-\mathrm{H} 1 \mathrm{C}$ & 109.5 & $\mathrm{C} 14-\mathrm{C} 9-\mathrm{C} 8$ & $119.3(3)$ \\
\hline $\mathrm{N} 1-\mathrm{C} 2-\mathrm{C} 3$ & $120.3(3)$ & $\mathrm{C} 11-\mathrm{C} 10-\mathrm{C} 9$ & $120.9(3)$ \\
\hline $\mathrm{N} 1-\mathrm{C} 2-\mathrm{H} 2 \mathrm{~A}$ & 119.9 & $\mathrm{C} 11-\mathrm{C} 10-\mathrm{H} 10$ & 119.6 \\
\hline $\mathrm{C} 3-\mathrm{C} 2-\mathrm{H} 2 \mathrm{~A}$ & 119.9 & $\mathrm{C} 9-\mathrm{C} 10-\mathrm{H} 10$ & 119.6 \\
\hline $\mathrm{C} 4-\mathrm{C} 3-\mathrm{C} 2$ & $120.6(3)$ & $\mathrm{C} 10-\mathrm{C} 11-\mathrm{C} 12$ & $120.8(3)$ \\
\hline $\mathrm{C} 4-\mathrm{C} 3-\mathrm{H} 3$ & 119.7 & $\mathrm{C} 10-\mathrm{C} 11-\mathrm{H} 11$ & 119.6 \\
\hline $\mathrm{C} 2-\mathrm{C} 3-\mathrm{H} 3$ & 119.7 & $\mathrm{C} 12-\mathrm{C} 11-\mathrm{H} 11$ & 119.6 \\
\hline $\mathrm{C} 3-\mathrm{C} 4-\mathrm{C} 5$ & $117.5(3)$ & $\mathrm{C} 13-\mathrm{C} 12-\mathrm{C} 11$ & $119.3(3)$ \\
\hline $\mathrm{C} 3-\mathrm{C} 4-\mathrm{C} 7$ & $124.8(3)$ & $\mathrm{C} 13-\mathrm{C} 12-\mathrm{H} 12$ & 120.3 \\
\hline $\mathrm{C} 5-\mathrm{C} 4-\mathrm{C} 7$ & $117.7(3)$ & $\mathrm{C} 11-\mathrm{C} 12-\mathrm{H} 12$ & 120.3 \\
\hline $\mathrm{C} 6-\mathrm{C} 5-\mathrm{C} 4$ & $120.4(3)$ & $\mathrm{C} 12-\mathrm{C} 13-\mathrm{C} 14$ & $119.7(3)$ \\
\hline $\mathrm{C} 6-\mathrm{C} 5-\mathrm{H} 5$ & 119.8 & $\mathrm{C} 12-\mathrm{C} 13-\mathrm{H} 13$ & 120.1 \\
\hline $\mathrm{C} 4-\mathrm{C} 5-\mathrm{H} 5$ & 119.8 & $\mathrm{C} 14-\mathrm{C} 13-\mathrm{H} 13$ & 120.1 \\
\hline $\mathrm{N} 1-\mathrm{C} 6-\mathrm{C} 5$ & $120.6(3)$ & $\mathrm{C} 13-\mathrm{C} 14-\mathrm{C} 9$ & $120.9(3)$ \\
\hline $\mathrm{N} 1-\mathrm{C} 6-\mathrm{H} 6$ & 119.7 & $\mathrm{C} 13-\mathrm{C} 14-\mathrm{H} 14$ & 119.5 \\
\hline $\mathrm{C} 5-\mathrm{C} 6-\mathrm{H} 6$ & 119.7 & $\mathrm{C} 9-\mathrm{C} 14-\mathrm{H} 14$ & 119.5 \\
\hline $\mathrm{C} 6-\mathrm{N} 1-\mathrm{C} 2-\mathrm{C} 3$ & $-1.2(5)$ & $\mathrm{C} 3-\mathrm{C} 4-\mathrm{C} 7-\mathrm{N} 2$ & $-14.7(4)$ \\
\hline $\mathrm{C} 1-\mathrm{N} 1-\mathrm{C} 2-\mathrm{C} 3$ & $-179.7(3)$ & $\mathrm{C} 5-\mathrm{C} 4-\mathrm{C} 7-\mathrm{N} 2$ & $166.9(3)$ \\
\hline $\mathrm{N} 1-\mathrm{C} 2-\mathrm{C} 3-\mathrm{C} 4$ & $0.2(5)$ & $\mathrm{C} 7-\mathrm{N} 2-\mathrm{C} 8-\mathrm{C} 9$ & $-88.1(4)$ \\
\hline $\mathrm{C} 2-\mathrm{C} 3-\mathrm{C} 4-\mathrm{C} 5$ & $0.1(5)$ & $\mathrm{N} 2-\mathrm{C} 8-\mathrm{C} 9-\mathrm{C} 10$ & $-24.3(4)$ \\
\hline $\mathrm{C} 2-\mathrm{C} 3-\mathrm{C} 4-\mathrm{C} 7$ & $-178.3(3)$ & $\mathrm{N} 2-\mathrm{C} 8-\mathrm{C} 9-\mathrm{C} 14$ & $157.9(3)$ \\
\hline $\mathrm{C} 3-\mathrm{C} 4-\mathrm{C} 5-\mathrm{C} 6$ & $0.6(5)$ & $\mathrm{C} 14-\mathrm{C} 9-\mathrm{C} 10-\mathrm{C} 11$ & $-1.7(5)$ \\
\hline $\mathrm{C} 7-\mathrm{C} 4-\mathrm{C} 5-\mathrm{C} 6$ & $179.1(3)$ & $\mathrm{C} 8-\mathrm{C} 9-\mathrm{C} 10-\mathrm{C} 11$ & $-179.5(3)$ \\
\hline $\mathrm{C} 2-\mathrm{N} 1-\mathrm{C} 6-\mathrm{C} 5$ & $1.9(5)$ & $\mathrm{C} 9-\mathrm{C} 10-\mathrm{C} 11-\mathrm{C} 12$ & $0.4(5)$ \\
\hline $\mathrm{C} 1-\mathrm{N} 1-\mathrm{C} 6-\mathrm{C} 5$ & $-179.6(3)$ & $\mathrm{C} 10-\mathrm{C} 11-\mathrm{C} 12-\mathrm{C} 13$ & $1.4(6)$ \\
\hline $\mathrm{C} 4-\mathrm{C} 5-\mathrm{C} 6-\mathrm{N} 1$ & $-1.6(5)$ & $\mathrm{C} 11-\mathrm{C} 12-\mathrm{C} 13-\mathrm{C} 14$ & $-1.7(6)$ \\
\hline $\mathrm{C} 8-\mathrm{N} 2-\mathrm{C} 7-\mathrm{O} 1$ & $3.0(5)$ & $\mathrm{C} 12-\mathrm{C} 13-\mathrm{C} 14-\mathrm{C} 9$ & $0.3(5)$ \\
\hline $\mathrm{C} 8-\mathrm{N} 2-\mathrm{C} 7-\mathrm{C} 4$ & $-177.1(2)$ & $\mathrm{C} 10-\mathrm{C} 9-\mathrm{C} 14-\mathrm{C} 13$ & $1.4(5)$ \\
\hline $\mathrm{C} 3-\mathrm{C} 4-\mathrm{C} 7-\mathrm{O} 1$ & $165.2(3)$ & $\mathrm{C} 8-\mathrm{C} 9-\mathrm{C} 14-\mathrm{C} 13$ & $179.2(3)$ \\
\hline $\mathrm{C} 5-\mathrm{C} 4-\mathrm{C} 7-\mathrm{O} 1$ & $-13.3(4)$ & & \\
\hline
\end{tabular}

Hydrogen-bond geometry $\left(\AA,{ }^{\circ}\right)$

\begin{tabular}{lllll}
\hline$D-\mathrm{H} \cdots A$ & $D-\mathrm{H}$ & $\mathrm{H} \cdots A$ & $D \cdots A$ & $D-\mathrm{H} \cdots A$ \\
\hline $\mathrm{N} 2-\mathrm{H} 2 \cdots \mathrm{C} 11$ & $0.92(3)$ & $2.26(3)$ & $3.163(3)$ & $165(2)$ \\
$\mathrm{C} 1-\mathrm{H} 1 C \cdots \mathrm{C} 11^{\mathrm{i}}$ & 0.96 & 2.89 & $3.513(3)$ & 124 \\
$\mathrm{C} 1-\mathrm{H} 1 A \cdots \mathrm{Cl} 1^{\mathrm{ii}}$ & 0.96 & 2.72 & $3.633(3)$ & 160 \\
$\mathrm{C} 2-\mathrm{H} 2 A \cdots \mathrm{Cl}{ }^{\mathrm{ii}}$ & 0.93 & 2.59 & $3.474(3)$ & 160 \\
$\mathrm{C} 3-\mathrm{H} 3 \cdots \mathrm{Cl} 1$ & 0.93 & 2.63 & $3.531(3)$ & 165 \\
\hline
\end{tabular}

Symmetry codes: (i) $-x+2,-y+1,-z+1$; (ii) $-x+2,-y+2,-z+1$.

4-[(Benzylamino)carbonyl]-1-methylpyridinium bromide (AmBr)

Crystal data

$\mathrm{C}_{14} \mathrm{H}_{15} \mathrm{~N}_{2} \mathrm{O}^{+} \cdot \mathrm{Br}^{-}$

$M_{r}=307.19$

Orthorhombic, $P 2_{1} 2_{1} 2_{1}$

$$
\begin{aligned}
& a=9.417(3) \AA \\
& b=11.099(5) \AA \\
& c=14.363(6) \AA
\end{aligned}
$$




$$
\begin{aligned}
& V=1501.2(10) \AA^{3} \\
& Z=4 \\
& F(000)=624 \\
& D_{\mathrm{x}}=1.359 \mathrm{Mg} \mathrm{m}^{-3} \\
& \text { Mo Ka radiation, } \lambda= \\
& \text { Cell parameters from } \\
& \text { Data collection } \\
& \text { Xcalibur, Sapphire3 } \\
& \quad \text { diffractometer }
\end{aligned}
$$

\section{Data collection}$$
\text { Mo } K \alpha \text { radiation, } \lambda=0.71073 \AA
$$

Cell parameters from 748 reflections

Radiation source: Enhance (Mo) X-ray Source Detector resolution: 16.1827 pixels $\mathrm{mm}^{-1}$

$\omega$ scans

Absorption correction: multi-scan

(CrysAlisPro, Rigaku OD 2018)

$T_{\min }=0.068, T_{\max }=1.000$

\section{Refinement}

Refinement on $F^{2}$

Least-squares matrix: full

$R\left[F^{2}>2 \sigma\left(F^{2}\right)\right]=0.063$

$w R\left(F^{2}\right)=0.150$

$S=1.00$

2635 reflections

164 parameters

0 restraints

Hydrogen site location: inferred from neighbouring sites

$$
\begin{aligned}
& \theta=3.2-24.8^{\circ} \\
& \mu=2.73 \mathrm{~mm}^{-1} \\
& T=293 \mathrm{~K} \\
& \text { Plate, yellow } \\
& 0.30 \times 0.30 \times 0.06 \mathrm{~mm}
\end{aligned}
$$

10683 measured reflections

2635 independent reflections

1583 reflections with $I>2 \sigma(I)$

$R_{\text {int }}=0.118$

$\theta_{\max }=25.0^{\circ}, \theta_{\min }=3.4^{\circ}$

$h=-11 \rightarrow 11$

$k=-13 \rightarrow 13$

$l=-17 \rightarrow 16$

H-atom parameters constrained

$w=1 /\left[\sigma^{2}\left(F_{\mathrm{o}}^{2}\right)+(0.0446 P)^{2}\right]$

where $P=\left(F_{\mathrm{o}}^{2}+2 F_{\mathrm{c}}^{2}\right) / 3$

$(\Delta / \sigma)_{\max }<0.001$

$\Delta \rho_{\max }=0.34 \mathrm{e} \AA^{-3}$

$\Delta \rho_{\min }=-0.60$ e $\AA^{-3}$

Absolute structure: Flack $x$ determined using 407 quotients $\left[\left(I^{+}\right)-(I)\right] /\left[\left(I^{+}\right)+\left(I^{-}\right)\right]$(Parsons et al., 2013)

Absolute structure parameter: 0.00 (2)

Special details

Geometry. All esds (except the esd in the dihedral angle between two 1.s. planes) are estimated using the full covariance matrix. The cell esds are taken into account individually in the estimation of esds in distances, angles and torsion angles; correlations between esds in cell parameters are only used when they are defined by crystal symmetry. An approximate (isotropic) treatment of cell esds is used for estimating esds involving l.s. planes.

Fractional atomic coordinates and isotropic or equivalent isotropic displacement parameters $\left(\AA^{2}\right)$

\begin{tabular}{lllll}
\hline & $x$ & $y$ & $z$ & $U_{\text {iso }} * / U_{\text {eq }}$ \\
\hline Br1 & $0.91899(12)$ & $0.26554(10)$ & $0.17853(8)$ & $0.0849(5)$ \\
O1 & $0.5589(10)$ & $0.6049(7)$ & $0.3657(5)$ & $0.091(3)$ \\
N2 & $0.7250(9)$ & $0.4630(7)$ & $0.3158(7)$ & $0.073(2)$ \\
H2 & 0.743714 & 0.406610 & 0.276630 & $0.088^{*}$ \\
N1 & $0.3008(10)$ & $0.4355(9)$ & $0.0832(7)$ & $0.073(2)$ \\
C7 & $0.5970(12)$ & $0.5238(9)$ & $0.3083(7)$ & $0.070(3)$ \\
C3 & $0.5277(11)$ & $0.3994(10)$ & $0.1584(8)$ & $0.071(3)$ \\
H3 & 0.612742 & 0.356784 & 0.159577 & $0.085^{*}$ \\
C2 & $0.4254(14)$ & $0.3763(9)$ & $0.0884(9)$ & $0.078(3)$ \\
H2A & 0.445066 & 0.317583 & 0.043984 & $0.093^{*}$ \\
C5 & $0.3663(13)$ & $0.5481(12)$ & $0.2211(9)$ & $0.090(4)$ \\
H5 & 0.343497 & 0.606658 & 0.264908 & $0.108^{*}$ \\
C4 & $0.4986(13)$ & $0.4888(10)$ & $0.2269(8)$ & $0.071(3)$ \\
C6 & $0.2692(14)$ & $0.5207(11)$ & $0.1512(10)$ & $0.095(4)$
\end{tabular}




$\begin{array}{lllll}\text { H6 } & 0.181979 & 0.559919 & 0.149850 & 0.114^{*} \\ \text { C9 } & 0.8166(12) & 0.4132(10) & 0.4771(8) & 0.073(3) \\ \text { C8 } & 0.8319(12) & 0.4919(11) & 0.3897(9) & 0.090(4) \\ \text { H8A } & 0.821881 & 0.575832 & 0.407276 & 0.108^{*} \\ \text { H8B } & 0.926489 & 0.481169 & 0.364293 & 0.108^{*} \\ \text { C13 } & 0.6899(13) & 0.3640(12) & 0.6235(8) & 0.085(4) \\ \text { H13 } & 0.616600 & 0.379851 & 0.665032 & 0.102^{*} \\ \text { C14 } & 0.7079(11) & 0.4343(11) & 0.5440(8) & 0.073(3) \\ \text { H14 } & 0.645855 & 0.498173 & 0.534234 & 0.088^{*} \\ \text { C12 } & 0.7868(15) & 0.2666(12) & 0.6398(9) & 0.098(4) \\ \text { H12 } & 0.776537 & 0.217390 & 0.691806 & 0.118^{*} \\ \text { C1 } & 0.1934(12) & 0.4075(14) & 0.0071(9) & 0.106(5) \\ \text { H1A } & 0.227194 & 0.341433 & -0.029942 & 0.158^{*} \\ \text { H1B } & 0.180938 & 0.477098 & -0.031718 & 0.158^{*} \\ \text { H1C } & 0.104155 & 0.386183 & 0.034937 & 0.158^{*} \\ \text { C10 } & 0.9118(15) & 0.3165(10) & 0.4951(9) & 0.096(4) \\ \text { H10 } & 0.984059 & 0.299441 & 0.453014 & 0.115^{*} \\ \text { C11 } & 0.8973(18) & 0.2467(12) & 0.5761(10) & 0.122(5) \\ \text { H11 } & 0.962607 & 0.185674 & 0.587752 & 0.147^{*}\end{array}$

Atomic displacement parameters $\left(\AA^{2}\right)$

\begin{tabular}{lllllll}
\hline & $U^{11}$ & $U^{22}$ & $U^{33}$ & $U^{12}$ & $U^{13}$ & $U^{23}$ \\
\hline Br1 & $0.0782(7)$ & $0.0895(8)$ & $0.0868(8)$ & $0.0122(7)$ & $0.0041(7)$ & $0.0018(7)$ \\
O1 & $0.106(6)$ & $0.085(5)$ & $0.083(6)$ & $0.013(5)$ & $-0.001(6)$ & $-0.023(4)$ \\
N2 & $0.077(6)$ & $0.074(6)$ & $0.068(6)$ & $-0.001(5)$ & $-0.002(6)$ & $-0.003(5)$ \\
N1 & $0.063(6)$ & $0.077(7)$ & $0.080(7)$ & $0.004(5)$ & $-0.002(5)$ & $0.000(5)$ \\
C7 & $0.084(7)$ & $0.066(7)$ & $0.060(7)$ & $0.000(6)$ & $0.011(7)$ & $0.014(5)$ \\
C3 & $0.071(7)$ & $0.072(7)$ & $0.071(8)$ & $0.006(5)$ & $-0.005(6)$ & $0.005(5)$ \\
C2 & $0.077(7)$ & $0.069(7)$ & $0.087(8)$ & $-0.003(7)$ & $0.020(8)$ & $-0.004(5)$ \\
C5 & $0.086(8)$ & $0.098(10)$ & $0.086(9)$ & $0.027(7)$ & $-0.006(8)$ & $-0.027(7)$ \\
C4 & $0.075(7)$ & $0.071(8)$ & $0.066(9)$ & $-0.006(6)$ & $0.005(7)$ & $0.004(6)$ \\
C6 & $0.072(8)$ & $0.103(10)$ & $0.111(12)$ & $0.025(7)$ & $0.001(8)$ & $-0.007(8)$ \\
C9 & $0.078(8)$ & $0.066(7)$ & $0.074(8)$ & $0.000(6)$ & $-0.012(7)$ & $0.001(6)$ \\
C8 & $0.074(7)$ & $0.102(10)$ & $0.094(10)$ & $-0.019(7)$ & $0.005(7)$ & $0.000(7)$ \\
C13 & $0.084(8)$ & $0.104(10)$ & $0.065(8)$ & $-0.015(8)$ & $0.007(7)$ & $-0.008(7)$ \\
C14 & $0.064(7)$ & $0.082(8)$ & $0.075(8)$ & $0.004(6)$ & $-0.010(7)$ & $-0.009(7)$ \\
C12 & $0.126(10)$ & $0.095(10)$ & $0.073(8)$ & $-0.011(9)$ & $-0.024(8)$ & $0.007(8)$ \\
C1 & $0.082(8)$ & $0.140(12)$ & $0.095(10)$ & $-0.004(9)$ & $-0.009(8)$ & $-0.014(9)$ \\
C10 & $0.095(9)$ & $0.104(9)$ & $0.088(9)$ & $0.032(9)$ & $-0.004(9)$ & $0.006(7)$ \\
C11 & $0.178(15)$ & $0.099(10)$ & $0.091(9)$ & $0.059(12)$ & $-0.027(11)$ & $-0.014(8)$ \\
& & & & & & \\
\hline
\end{tabular}

Geometric parameters $\left(A,{ }^{\circ}\right)$

\begin{tabular}{llll}
\hline $\mathrm{O} 1-\mathrm{C} 7$ & $1.273(12)$ & $\mathrm{C} 9-\mathrm{C} 14$ & $1.423(14)$ \\
$\mathrm{N} 2-\mathrm{C} 7$ & $1.386(12)$ & $\mathrm{C} 9-\mathrm{C} 8$ & $1.536(15)$ \\
$\mathrm{N} 2-\mathrm{C} 8$ & $1.498(14)$ & $\mathrm{C} 8-\mathrm{H} 8 \mathrm{~A}$ & 0.9700 \\
$\mathrm{~N} 2-\mathrm{H} 2$ & 0.8600 & $\mathrm{C} 8-\mathrm{H} 8 \mathrm{~B}$ & 0.9700
\end{tabular}




\begin{tabular}{|c|c|c|c|}
\hline $\mathrm{N} 1-\mathrm{C} 2$ & $1.347(14)$ & $\mathrm{C} 13-\mathrm{C} 14$ & $1.392(15)$ \\
\hline $\mathrm{N} 1-\mathrm{C} 6$ & $1.392(14)$ & $\mathrm{C} 13-\mathrm{C} 12$ & $1.433(16)$ \\
\hline $\mathrm{N} 1-\mathrm{C} 1$ & $1.521(13)$ & $\mathrm{C} 13-\mathrm{H} 13$ & 0.9300 \\
\hline $\mathrm{C} 7-\mathrm{C} 4$ & $1.540(15)$ & C14-H14 & 0.9300 \\
\hline $\mathrm{C} 3-\mathrm{C} 2$ & $1.416(15)$ & $\mathrm{C} 12-\mathrm{C} 11$ & $1.404(18)$ \\
\hline $\mathrm{C} 3-\mathrm{C} 4$ & $1.425(14)$ & $\mathrm{C} 12-\mathrm{H} 12$ & 0.9300 \\
\hline $\mathrm{C} 3-\mathrm{H} 3$ & 0.9300 & $\mathrm{C} 1-\mathrm{H} 1 \mathrm{~A}$ & 0.9600 \\
\hline $\mathrm{C} 2-\mathrm{H} 2 \mathrm{~A}$ & 0.9300 & $\mathrm{C} 1-\mathrm{H} 1 \mathrm{~B}$ & 0.9600 \\
\hline $\mathrm{C} 5-\mathrm{C} 6$ & $1.392(16)$ & $\mathrm{C} 1-\mathrm{H} 1 \mathrm{C}$ & 0.9600 \\
\hline $\mathrm{C} 5-\mathrm{C} 4$ & $1.412(14)$ & $\mathrm{C} 10-\mathrm{C} 11$ & $1.404(17)$ \\
\hline $\mathrm{C} 5-\mathrm{H} 5$ & 0.9300 & $\mathrm{C} 10-\mathrm{H} 10$ & 0.9300 \\
\hline $\mathrm{C} 6-\mathrm{H} 6$ & 0.9300 & $\mathrm{C} 11-\mathrm{H} 11$ & 0.9300 \\
\hline $\mathrm{C} 9-\mathrm{C} 10$ & $1.422(15)$ & & \\
\hline $\mathrm{C} 7-\mathrm{N} 2-\mathrm{C} 8$ & $122.4(9)$ & $\mathrm{N} 2-\mathrm{C} 8-\mathrm{C} 9$ & $113.2(9)$ \\
\hline $\mathrm{C} 7-\mathrm{N} 2-\mathrm{H} 2$ & 118.8 & $\mathrm{~N} 2-\mathrm{C} 8-\mathrm{H} 8 \mathrm{~A}$ & 108.9 \\
\hline $\mathrm{C} 8-\mathrm{N} 2-\mathrm{H} 2$ & 118.8 & $\mathrm{C} 9-\mathrm{C} 8-\mathrm{H} 8 \mathrm{~A}$ & 108.9 \\
\hline $\mathrm{C} 2-\mathrm{N} 1-\mathrm{C} 6$ & $118.6(11)$ & $\mathrm{N} 2-\mathrm{C} 8-\mathrm{H} 8 \mathrm{~B}$ & 108.9 \\
\hline $\mathrm{C} 2-\mathrm{N} 1-\mathrm{C} 1$ & $121.3(10)$ & $\mathrm{C} 9-\mathrm{C} 8-\mathrm{H} 8 \mathrm{~B}$ & 108.9 \\
\hline $\mathrm{C} 6-\mathrm{N} 1-\mathrm{C} 1$ & $120.0(10)$ & $\mathrm{H} 8 \mathrm{~A}-\mathrm{C} 8-\mathrm{H} 8 \mathrm{~B}$ & 107.7 \\
\hline $\mathrm{O} 1-\mathrm{C} 7-\mathrm{N} 2$ & $122.6(11)$ & $\mathrm{C} 14-\mathrm{C} 13-\mathrm{C} 12$ & $118.6(11)$ \\
\hline $\mathrm{O} 1-\mathrm{C} 7-\mathrm{C} 4$ & $120.0(10)$ & $\mathrm{C} 14-\mathrm{C} 13-\mathrm{H} 13$ & 120.7 \\
\hline $\mathrm{N} 2-\mathrm{C} 7-\mathrm{C} 4$ & $117.4(10)$ & $\mathrm{C} 12-\mathrm{C} 13-\mathrm{H} 13$ & 120.7 \\
\hline $\mathrm{C} 2-\mathrm{C} 3-\mathrm{C} 4$ & $119.1(10)$ & $\mathrm{C} 13-\mathrm{C} 14-\mathrm{C} 9$ & $123.3(11)$ \\
\hline $\mathrm{C} 2-\mathrm{C} 3-\mathrm{H} 3$ & 120.5 & $\mathrm{C} 13-\mathrm{C} 14-\mathrm{H} 14$ & 118.4 \\
\hline $\mathrm{C} 4-\mathrm{C} 3-\mathrm{H} 3$ & 120.5 & C9-C14-H14 & 118.4 \\
\hline $\mathrm{N} 1-\mathrm{C} 2-\mathrm{C} 3$ & $122.9(10)$ & $\mathrm{C} 11-\mathrm{C} 12-\mathrm{C} 13$ & $118.9(12)$ \\
\hline $\mathrm{N} 1-\mathrm{C} 2-\mathrm{H} 2 \mathrm{~A}$ & 118.5 & $\mathrm{C} 11-\mathrm{C} 12-\mathrm{H} 12$ & 120.6 \\
\hline $\mathrm{C} 3-\mathrm{C} 2-\mathrm{H} 2 \mathrm{~A}$ & 118.5 & $\mathrm{C} 13-\mathrm{C} 12-\mathrm{H} 12$ & 120.6 \\
\hline $\mathrm{C} 6-\mathrm{C} 5-\mathrm{C} 4$ & $121.4(11)$ & $\mathrm{N} 1-\mathrm{C} 1-\mathrm{H} 1 \mathrm{~A}$ & 109.5 \\
\hline $\mathrm{C} 6-\mathrm{C} 5-\mathrm{H} 5$ & 119.3 & $\mathrm{~N} 1-\mathrm{C} 1-\mathrm{H} 1 \mathrm{~B}$ & 109.5 \\
\hline $\mathrm{C} 4-\mathrm{C} 5-\mathrm{H} 5$ & 119.3 & $\mathrm{H} 1 \mathrm{~A}-\mathrm{C} 1-\mathrm{H} 1 \mathrm{~B}$ & 109.5 \\
\hline $\mathrm{C} 5-\mathrm{C} 4-\mathrm{C} 3$ & $117.0(11)$ & $\mathrm{N} 1-\mathrm{C} 1-\mathrm{H} 1 \mathrm{C}$ & 109.5 \\
\hline $\mathrm{C} 5-\mathrm{C} 4-\mathrm{C} 7$ & $117.3(10)$ & $\mathrm{H} 1 \mathrm{~A}-\mathrm{C} 1-\mathrm{H} 1 \mathrm{C}$ & 109.5 \\
\hline $\mathrm{C} 3-\mathrm{C} 4-\mathrm{C} 7$ & $125.7(11)$ & $\mathrm{H} 1 \mathrm{~B}-\mathrm{C} 1-\mathrm{H} 1 \mathrm{C}$ & 109.5 \\
\hline $\mathrm{C} 5-\mathrm{C} 6-\mathrm{N} 1$ & $121.0(11)$ & $\mathrm{C} 11-\mathrm{C} 10-\mathrm{C} 9$ & $120.4(12)$ \\
\hline $\mathrm{C} 5-\mathrm{C} 6-\mathrm{H} 6$ & 119.5 & $\mathrm{C} 11-\mathrm{C} 10-\mathrm{H} 10$ & 119.8 \\
\hline $\mathrm{N} 1-\mathrm{C} 6-\mathrm{H} 6$ & 119.5 & $\mathrm{C} 9-\mathrm{C} 10-\mathrm{H} 10$ & 119.8 \\
\hline $\mathrm{C} 10-\mathrm{C} 9-\mathrm{C} 14$ & $117.0(11)$ & $\mathrm{C} 10-\mathrm{C} 11-\mathrm{C} 12$ & $121.7(13)$ \\
\hline $\mathrm{C} 10-\mathrm{C} 9-\mathrm{C} 8$ & $121.2(11)$ & $\mathrm{C} 10-\mathrm{C} 11-\mathrm{H} 11$ & 119.2 \\
\hline $\mathrm{C} 14-\mathrm{C} 9-\mathrm{C} 8$ & $121.8(10)$ & $\mathrm{C} 12-\mathrm{C} 11-\mathrm{H} 11$ & 119.2 \\
\hline $\mathrm{C} 8-\mathrm{N} 2-\mathrm{C} 7-\mathrm{O} 1$ & $-2.8(15)$ & $\mathrm{C} 2-\mathrm{N} 1-\mathrm{C} 6-\mathrm{C} 5$ & $2.6(18)$ \\
\hline $\mathrm{C} 8-\mathrm{N} 2-\mathrm{C} 7-\mathrm{C} 4$ & $177.7(9)$ & $\mathrm{C} 1-\mathrm{N} 1-\mathrm{C} 6-\mathrm{C} 5$ & $-179.7(13)$ \\
\hline $\mathrm{C} 6-\mathrm{N} 1-\mathrm{C} 2-\mathrm{C} 3$ & $-2.0(17)$ & $\mathrm{C} 7-\mathrm{N} 2-\mathrm{C} 8-\mathrm{C} 9$ & $93.5(12)$ \\
\hline $\mathrm{C} 1-\mathrm{N} 1-\mathrm{C} 2-\mathrm{C} 3$ & $-179.7(10)$ & $\mathrm{C} 10-\mathrm{C} 9-\mathrm{C} 8-\mathrm{N} 2$ & $103.8(12)$ \\
\hline $\mathrm{C} 4-\mathrm{C} 3-\mathrm{C} 2-\mathrm{N} 1$ & $0.2(16)$ & $\mathrm{C} 14-\mathrm{C} 9-\mathrm{C} 8-\mathrm{N} 2$ & $-76.9(13)$ \\
\hline $\mathrm{C} 6-\mathrm{C} 5-\mathrm{C} 4-\mathrm{C} 3$ & $-0.3(19)$ & $\mathrm{C} 12-\mathrm{C} 13-\mathrm{C} 14-\mathrm{C} 9$ & $1.1(17)$ \\
\hline
\end{tabular}




\section{supporting information}

$\begin{array}{llll}\mathrm{C} 6-\mathrm{C} 5-\mathrm{C} 4-\mathrm{C} 7 & -178.7(11) & \mathrm{C} 10-\mathrm{C} 9-\mathrm{C} 14-\mathrm{C} 13 & -1.4(16) \\ \mathrm{C} 2-\mathrm{C} 3-\mathrm{C} 4-\mathrm{C} 5 & 0.9(16) & \mathrm{C} 8-\mathrm{C} 9-\mathrm{C} 14-\mathrm{C} 13 & 179.3(10) \\ \mathrm{C} 2-\mathrm{C} 3-\mathrm{C} 4-\mathrm{C} 7 & 179.1(10) & \mathrm{C} 14-\mathrm{C} 13-\mathrm{C} 12-\mathrm{C} 11 & 0.9(17) \\ \mathrm{O} 1-\mathrm{C} 7-\mathrm{C} 4-\mathrm{C} 5 & -1.4(16) & \mathrm{C} 14-\mathrm{C} 9-\mathrm{C} 10-\mathrm{C} 11 & -0.3(18) \\ \mathrm{N} 2-\mathrm{C} 7-\mathrm{C} 4-\mathrm{C} 5 & 178.0(10) & \mathrm{C} 8-\mathrm{C} 9-\mathrm{C} 10-\mathrm{C} 11 & 179.1(12) \\ \mathrm{O} 1-\mathrm{C} 7-\mathrm{C} 4-\mathrm{C} 3 & -179.6(10) & \mathrm{C} 9-\mathrm{C} 10-\mathrm{C} 11-\mathrm{C} 12 & 2(2) \\ \mathrm{N} 2-\mathrm{C} 7-\mathrm{C} 4-\mathrm{C} 3 & -0.2(15) & \mathrm{C} 13-\mathrm{C} 12-\mathrm{C} 11-\mathrm{C} 10 & -3(2) \\ \mathrm{C} 4-\mathrm{C} 5-\mathrm{C} 6-\mathrm{N} 1 & -1(2) & & \end{array}$

Hydrogen-bond geometry $\left(A,{ }^{\circ}\right)$

\begin{tabular}{lllll}
\hline$D-\mathrm{H} \cdots A$ & $D-\mathrm{H}$ & $\mathrm{H} \cdots A$ & $D \cdots A$ & $D-\mathrm{H} \cdots A$ \\
\hline $\mathrm{N} 2-\mathrm{H} 2 \cdots \mathrm{Br} 1$ & 0.86 & 2.68 & $3.468(9)$ & 154 \\
$\mathrm{C} 1-\mathrm{H} 1 A \cdots \mathrm{Br} 1^{\mathrm{i}}$ & 0.96 & 3.04 & $3.913(13)$ & 152 \\
$\mathrm{C} 1-\mathrm{H} 1 C \cdots \mathrm{Br} 1^{\mathrm{ii}}$ & 0.96 & 3.01 & $3.901(13)$ & 154
\end{tabular}

Symmetry codes: (i) $x-1 / 2,-y+1 / 2,-z$; (ii) $x-1, y, z$. 